\title{
Enhancement of RANKL-induced MITF-E expression and osteoclastogenesis by TGF- $\beta$
}

$\operatorname{AUTHOR}(S)$ :

Asai, Kumiko; Funaba, Masayuki; Murakami, Masaru

\section{CITATION:}

Asai, Kumiko ...[et al]. Enhancement of RANKL-induced MITF-E expression and osteoclastogenesis by TGF- $\beta$. Cell biochemistry and function 2014, 32(5): 401-409

ISSUE DATE:

2014-02-12

URL:

http://hdl.handle.net/2433/198735

\section{RIGHT:}

This is the peer reviewed version of the following article: Asai, K., Funaba, M. and Murakami, M. (2014), Enhancement of RANKL-induced MITF-E expression and osteoclastogenesis by TGF- $\beta$. Cell Biochem. Funct., 32: 401-409, which has been published in final form at http://dx.doi.org/10.1002/cbf.3028. This article may be used for non-commercial purposes in accordance with Wiley Terms and Conditions for Self-Archiving.; This is not the published version. Please cite only the published version.; この論文は出版社版でありません。引用の際には出版社版をご確認ご利用ください。 


\section{Enhancement of RANKL-induced MITF-E expression and osteoclastogenesis by TGF- $\beta$}

Kumiko Asai ${ }^{1}$, Masayuki Funaba ${ }^{2 \star}$ and Masaru Murakami ${ }^{1 \star}$

${ }^{1}$ Laboratory of Molecular Biology, Azabu University School of Veterinary Medicine, Sagamihara 252-5201, Japan

${ }^{2}$ Division of Applied Biosciences, Graduate School of Agriculture, Kyoto University, Kyoto 606-8502, Japan

Running title: Osteoclastogenesis by MITF-E and TGF- $\beta$

*Correspondence:

Masayuki Funaba, Division of Applied Biosciences, Graduate School of Agriculture, Kyoto University (mfunaba@kais.kyoto-u.ac.jp) or Masaru Murakami, Laboratory of Molecular Biology, Azabu University School of Veterinary Medicine (murakami@azabu-u.ac.jp) 


\section{Abstract}

MITF is a transcription factor that is expressed in limited types of cells, including osteoclasts, but the expression and role of MITF during osteoclastogenesis has not been fully elucidated. The expression of the MITF-E isoform but not that of the MITF-A isoform was induced in response to differentiation stimulation toward osteoclasts by RANKL in both RAW264.7 cells and primary bone marrow cells. The RANKL-induced formation of TRAP-positive multinucleated cells was inhibited in RAW264.7 cells expressing siRNA for MITF-E. TGF- $\beta$ enhanced RANKL-induced MITF-E expression and TRAP-positive multinucleated cell formation. In particular, TGF- $\beta$ potentiated the formation of larger osteoclasts. The expression levels of NFATc1, TRAP and CtsK, genes related to osteoclast development and activity, were concurrently enhanced by TGF- $\beta$ in the presence of RANKL. Furthermore, the expression of DC-STAMP, Itgav, Itga2, Itga5, Itgb1, Itgb3, and Itgb5, genes related to cell adhesion and fusion, was up-regulated by co-treatment with TGF- $\beta$. In particular, the regulatory expression of Itgav and Itgb5 in response to RANKL with or without TGF- $\beta$ resembled that of MITF-E. Because MITF is involved in cell fusion in some cell systems, these results imply a role for MITF-E as an enhancer of osteoclastogenesis, and that RANKL-induced levels of both MITF-E mRNA and of MITF-dependent gene expression are enhanced by treatment with TGF- $\beta$.

KEY WORDS: osteoclastogenesis; MITF; TGF- $\beta$; cell fusion; integrins 


\section{INTRODUCTION}

Osteoclasts, which degrade bone matrix through the secretion of acid and various enzymes, ${ }^{1-3}$ are tartrate-resistant acid phosphatase (TRAP)-positive multinucleated cells formed by the fusion of precursor cells of monocyte-macrophage lineage. ${ }^{4,5}$ Osteoclast differentiation is supported by osteoblasts and stromal cells, which produce factors affecting the number and activity of osteoclasts. Macrophage-colony-stimulating factor (M-CSF) and receptor activator of $\mathrm{NF}-\kappa \mathrm{B}$ ligand (RANKL) principally regulate osteoclastogenesis. M-CSF is required for the survival and proliferation of osteoclast precursor cells. ${ }^{4,5}$ In contrast, RANKL stimulates osteoclast differentiation through regulatory expression of osteoclastogenesis-related transcription factors including NFATc1. ${ }^{4,5}$

In addition to these molecules, various cytokines, including transforming growth factor- $\beta$ (TGF- $\beta$ ), are involved in osteoclastogenesis. ${ }^{3,6,7}$ TGF- $\beta$ is a pluripotent growth factor that modulates cell differentiation and maturation in diverse types of cells. ${ }^{7,8}$ Although the effects of TGF- $\beta$ on osteoclast differentiation depend on the cell culture system and the stage of osteoclast differentiation, ${ }^{7,8}$ TGF- $\beta$ consistently stimulates RANKL-induced osteoclastogenesis in differentiation models using RAW264.7 cells. $^{9-11}$ The detailed mechanism underlying the enhanced osteoclastogenesis by TGF- $\beta$ in RAW264.7 cells is not, as of yet, fully characterized.

The regulation of osteoclast differentiation and maturation is not determined only by secreted proteins from osteoblasts and stromal cells. Microphthalmia-associated transcription factor (MITF) is a transcription factor expressed in a tissue-specific manner. $^{12,} 13$ MITF is also expressed in monocyte-macrophage lineage cells and osteoclasts. ${ }^{14}$ The Mitf ${ }^{m i}$ allele produces an impaired bone phenotype. The bones of Mitf ${ }^{m i} / M_{i t f}{ }^{m i}$ mice present signs of osteopetrosis due to a lack of functional osteoclasts. ${ }^{14,}$ 
${ }^{15}$ MITF regulates osteoclastogenesis in at least two steps. First, MITF up-regulates the expression of genes related to osteoclast activity such as TRAP, ${ }^{16}$ chloride channel $7,{ }^{17}$ cathepsin $\mathrm{K}(\mathrm{CtsK})^{18}$ and $\mathrm{v}$-ATPase $\mathrm{d} 2 .{ }^{19}$ Second, MITF governs osteoclast development through the regulation of cell fusion. DC-STAMP is required for efficient cell-cell fusion of osteoclasts, ${ }^{20}$ and transcription of DC-STAMP is positively regulated by MITF. ${ }^{21}$ The activity of MITF in stimulating cell fusion has also been shown in different cell types. MITF expression in myoblasts and nascent myotubes is essential for the maturation of myotubes via the up-regulation of integrin $\alpha_{9}$ (Itga9) expression. ${ }^{13}$

MITF is expressed as a series of isoforms differing in their first exons and promoters. ${ }^{22-24}$ For most isoforms, the initial exon, which is isoform-specific exon, is spliced onto the later part of exon $1 \mathrm{~B}$ and then to the common exons $2-9 ; ;^{22-24}$ at present nine MITF isoforms have been identified in mice, i.e., MITF-A, -B, -C, -D, -E, -H, -J, -M and -mc. MITF isoforms are expressed in a cell type-specific manner. ${ }^{25-28}$ Transcriptional activities of MITF are overlapped but distinct among MITF isoforms depending on the target gene. ${ }^{29-33}$

Here, we explored the role of MITF during osteoclastogenesis and the relationship between MITF-E isoform and the TGF- $\beta$ pathway. Our results indicate that the MITF-E isoform is induced in differentiating osteoclasts, and the expression is required for efficient osteoclast formation. In addition, TGF- $\beta$ enhances the expression level of MITF-E induced by RANKL and potentiates the formation of larger osteoclasts, possibly through the up-regulation of integrins.

\section{MATERIALS AND METHODS}

\section{Materials}


The following reagents were purchased: recombinant murine M-CSF and recombinant murine soluble RANKL from Peprotech (Rocky Hill, NJ, USA) and recombinant human TGF- $\beta 1$ from R\&D Systems (Minneapolis, MN, USA).

\section{Cell culture}

RAW264.7 cells were cultured in $\alpha$-MEM with 6\% heat-inactivated FBS, $100 \mathrm{U} / \mathrm{ml}$ penicillin and $100 \mu \mathrm{g} / \mathrm{ml}$ streptomycin at $37^{\circ} \mathrm{C}$ under a humidified $5 \% \mathrm{CO}_{2}$ atmosphere. Primary osteoclasts were basically differentiated as described by Sankar et al. ${ }^{34}$ Bone marrow cells were obtained from the femurs of adult C57BL/6 mice and cultured for 3 days in basal medium, i.e., DMEM with 10\% heat-inactivated FBS, $100 \mathrm{U} / \mathrm{ml}$ penicillin and $100 \mu \mathrm{g} / \mathrm{ml}$ streptomycin, supplemented with M-CSF (50 ng/ml). Subsequently, the cells were cultured in the basal medium supplemented with M-CSF (25 ng/ml) in the presence or absence of recombinant soluble RANKL (50 ng/ml). The animal experiments were approved by the Animal Care and Use Committees of Azabu University.

\section{Histochemical detection of TRAP}

TRAP was detected by staining of fixed cells by use of an Acid Phosphatase, Leukocyte kit (Sigma, St. Louis, MO, USA) according to the manufacturer's protocol. The cells were counter-stained with hematoxylin, and the number of cells with more than 3 nuclei was counted. In addition, the area of TRAP-positive cells was measured by the use of Image $\mathrm{J}$ software, and the number of TRAP-positive cells was counted for every cell size.

\section{Osteoclast function assay}

Osteoclast functionality was examined via a pit formation assay using 96-well Corning Osteo Assay plates (Corning Inc., Corning, NY, USA) according to the manufacturer's 
protocol. The pits were observed via light microscopy. The pit area was measured using Image $\mathrm{J}$ software, and the total pit area per well was calculated.

\section{SiRNA transfection}

The siRNA for MITF-E were prepared (Bonac Inc., Kurume, Japan). The nucleotide sequences used were 5'-GGUUACGUAUCUUGUCCACAG-3' and 5'GUGGACAAGAUACGUAACCUC-3'. As a control, siRNA for GFP was used. ${ }^{35}$ For RT-qPCR analyses, 20 pmol of siRNA was transfected into RAW264.7 cells seeded at a density of $2.5 \times 10^{4}$ cells in 24 -well plates at 24 hours before transfection. For morphological evaluation, 4 pmol of siRNA was transfected in cells seeded at a density of $4 \times 10^{3}$ cells in 96-well plates. The transfection of siRNA was conducted by use of Lipofectamine RNAiMAX (Life Technologies, Carlsbad, CA, USA) according to the manufacturer's protocol. At 8 hours after transfection, the cells were treated with RANKL (50 ng/ml) for 24 hours.

\section{RNA isolation and RT-quantitative PCR (RT-qPCR)}

Total RNA was isolated by use of QuickGene RNA cultured cell kit S (Wako, Osaka, Japan) in QuickGene-810 (Wako, Osaka, Japan), an automatic nucleic acid extraction system, according to the manufacturer's protocol. The concentration of RNA was determined from the absorbance at $260 \mathrm{~nm}$. The cDNA was synthesized by use of High Capacity cDNA Reverse Transcription Kit with RNase Inhibitor (Life Technologies, Carlsbad, CA, USA), according to the manufacturer's protocol. The cDNA corresponding to $5 \mathrm{ng}$ of total RNA was used as a template of real-time qPCR; qPCR was performed by use of SYBR Premix Ex-taq II (Takara, Otsu, Japan) in Thermal Cycler Dice Real Time System TP800 (Takara, Otsu, Japan), according to the manufacturer's protocol. The profile of qPCR is as follows: after denature for $30 \mathrm{sec}$ at $95^{\circ} \mathrm{C}, 40$ cycles consisting of $5 \mathrm{sec}$ at $95^{\circ} \mathrm{C}$ and $30 \mathrm{sec}$ at $60^{\circ} \mathrm{C}$. Subsequently, melting 
curve analyses were performed by increasing temperature from $60^{\circ} \mathrm{C}$ to $95^{\circ} \mathrm{C}$ to verify that the PCR products are not primer dimers but single products. Gene transcript level in each sample was determined by standard curve method; the standard DNA was prepared as described below. The PCR primers used are presented in Table 1. The 5'-primers for MITF-A and -E were selected from the respective isoform-specific region; the specificity of the PCR primers was also verified by agarose gel electrophoresis of the PCR product and subsequent staining with ethidium bromide. The relative mRNA level was expressed as a ratio with the G3PDH mRNA level. When the gene expression level was below detection limit, it was assumed to express at the detection limit.

\section{Preparation of standard DNA}

To examine time-course changes in the expression of MITF isoforms, the number of cDNA molecules was precisely quantified as described previously. ${ }^{35}$ Briefly, the cDNA for MITF-A, MITF-E and G3PDH was individually amplified by PCR. The PCR product by use of Wizard SV Gel and PCR Clean-Up System (Promega, Madison, WI, USA). The amount of the PCR product was precisely quantified by use of a DNA 1000 Lab Chip Kit (Agilent Technologies, Santa Clara, CA, USA) in an Agilent2100 bioanalyzer (Agilent Technologies, Santa Clara, CA, USA). The molecular number of the PCR product was calculated from the DNA mass and the molecular weight. Several levels of the PCR product were prepared by serial dilution, and used as standard solutions of qPCR.

\section{Statistical analysis}

All the experiments were basically performed 2 or more times; each experiment was done in triplicate. The data of a representative experiment are presented as the mean \pm SE $(n=3)$. Comparisons between the cells treated with RANKL alone and the other cells, and comparisons between cells transfected with siRNA for GFP and those with 
MITF-E siRNA were conducted using Student's $t$-test. The results were considered statistically significant at $P<0.05$.

\section{RESULTS AND DISCUSSION}

The changes in gene expression of MITF isoforms during osteoclastogenesis were examined (Fig. 1). Because RAW264.7 cells synthesize sufficient M-CSF, ${ }^{36}$ only exogenous RANKL is required for the formation of TRAP-positive multinucleated cells. In contrast, both M-CSF and RANKL must be exogenously supplied in primary bone marrow cell culture. The MITF-A isoform was expressed in both RAW264.7 cells (Fig. 1A) and bone marrow cells (Fig. 1B). The expression level was relatively constant during osteoclastogenesis in both RAW264.7 cells and bone marrow cells, except for the higher expression of MITF-A in bone marrow cells on day 3 without RANKL (Fig. 1B). In contrast, the gene transcript levels of MITF-E were increased within 1 day in response to treatment with RANKL in RAW264.7 cells (9-fold, Fig. 1C) and in bone marrow cells (1000-fold, Fig. 1D). RANKL-induced MITF-E expression was gradually decreased with incubation days in RAW264.7 cells, and the effect of RANKL treatment was not significant on day 3. In contrast, the up-regulation of MITF-E with treatment with M-CSF and RANKL was maintained for at least 3 days in bone marrow cells. Treatment with M-CSF alone had no effects on MITF-E expression in bone marrow cells (data not shown). Significant expression of the other MITF isoforms was not detected (data not shown). Lu et al. showed up-regulation of MITF-E expression in response to RANKL treatment by semi-quantitative RT-PCR analyses. ${ }^{37}$ In the present study, we quantitatively reveal specific induction of MITF-E mRNA during osteoclastogenesis.

The role of induced MITF-E in the formation of osteoclastic cells was evaluated next. 
RAW264.7 cells were transfected with MITF-E siRNA prior to RANKL treatment. MITF-E siRNA potentiated a decrease in the number of TRAP-positive multinucleated cells (Fig. 2A and B), suggesting a positive role for the induced MITF-E in osteoclastogenesis. The MITF-E gene transcript level was reproducibly decreased by transfection with the siRNA (Fig. 2C, data not shown). MITF-E isoform-specific region is only 139 bp. We designed possible 2 siRNAs for MITF-E; the knockdown efficiency and reproducibility of the knockdown is better for the siRNA used in this study (data not shown), although nevertheless the inhibition of MITF-E expression is limited. The knockdown of MITF-E gene did not affect the expression level of MITF-A (Fig. 2D). Transfection of siRNA for MITF-E inhibited RANKL-induced expression of TRAP and CtsK, genes related to osteoclast activity, ${ }^{16,18}$ on day 3 (Fig. 2E and F). Lu et al. also showed the blockage of MITF-E gene induction results in the impaired formation of osteoclasts; ${ }^{37}$ we also observed the similar results. All these results suggest that transient induction of MITF-E by RANKL is essential for efficient osteoclastogenesis. ${ }^{37}$

Next, the effects of TGF- $\beta$ on osteoclastogenesis were examined in RAW264.7 cells. Treatment with TGF- $\beta$ alone did not induce formation of TRAP-positive multinucleated cells, but TGF- $\beta$ increased the number of TRAP-positive multinucleated cells induced by RANKL (Fig. 3A and B), which was consistent with previous results. ${ }^{9-11}$ We also noticed that larger TRAP-positive multinucleated cells were formed by co-treatment with TGF- $\beta$ compared with the treatment with RANKL alone. Chin et al. ${ }^{11}$ described the TGF- $\beta$-induced formation of giant osteoclasts but did not quantitatively analyze them. To characterize the cell size in detail, the number of TRAP-positive multinucleated cells was counted for every cell size (Fig. 3C). The proportion of cells with areas $>1 \times 10^{4}$ and $<2 \times 10^{4} \mu \mathrm{m}^{2}$ was significantly increased by TGF- $\beta$ treatment, whereas the proportion of cells with areas $<5 \times 10^{3} \mu \mathrm{m}^{2}$ tended to be decreased, indicating that TGF- $\beta$ accelerates the formation of larger TRAP-positive multinucleated cells. TGF- $\beta$ 
also increased bone resorption activity, and RANKL-induced pit formation was enhanced by the co-treatment with TGF- $\beta$ (Fig. 3D and E). The present results suggest that TGF- $\beta$ acts not only as an enhancer of osteoclast formation induced by RANKL but also as an accelerator of mature osteoclast formation through cell fusion of nascent osteoclasts.

The molecular basis of enhanced osteoclastogenesis by TGF- $\beta$ was then explored. The expression of NFATc1, which is involved in the onset of osteoclastogenesis, ${ }^{38,} 39$ was increased within 1 day after treatment with RANKL, and TGF- $\beta$ enhanced RANKL-induced NFATc1 expression (Fig. 4A). Similarly, RANKL-induced MITF-E expression was further up-regulated by TGF- $\beta$ (Fig. 4B). The TGF- $\beta$ treatment also significantly increased gene transcript level of MITF-A, but the extent of increase in the expression was relatively small ( 2-fold, Fig. 4C). In accordance with the enhancement of expression related to the triggering of osteoclastogenesis, TGF- $\beta$ further increased the expression of TRAP and CtsK on day 3 (Fig. 4D and E).

The expression of the genes involved in cell fusion was further examined. DC-STAMP is a master regulator of cell fusion in osteoclast formation. ${ }^{40,41}$ The expression of DC-STAMP was induced by RANKL treatment, and TGF- $\beta$ slightly but significantly enhanced the RANKL-induced expression (Fig. 5A).

We evaluated the gene transcript levels of integrins and ADAMs. Integrins and ADAMs are also involved in the adhesion and fusion of monocyte/macrophage-lineage cells. ${ }^{41,42}$ Several integrin proteins, such as integrin $\alpha_{V}$ (Itgav), $\alpha_{2}$ (Itga2), $\alpha_{5}$ (Itga5), $\beta_{1}$ (Itgb1) and $\beta_{5}$ (Itgb5), are expressed in human osteoclasts. ${ }^{43}$ The forced expression of Itgav stimulated the formation of TRAP-negative multinucleated cells in RAW264.7 cells, and RANKL changed these cells to TRAP-positive cells. ${ }^{11}$ Anti-Itga9 antibody partly 
inhibited M-CSF and RANKL-induced osteoclast formation. ${ }^{44}$ Bone marrow cells prepared from integrin $\beta_{3}$ (Itgb3)-null mice are less differentiated into osteoclasts in vitro. ${ }^{45}$ Furthermore, the down-regulation of ADAM8 and ADAM12 expression inhibits osteoclast formation as well as cell fusion of macrophages. ${ }^{46,47}$ The expression levels of Itgav, Itga2, Itga5, Itgb1, Itgb3 and Itgb5 were significantly higher in cells treated with RANKL and TGF- $\beta$ than in cells treated with RANKL alone (Fig. 5B-G). In contrast, the expression of ADAM8 and ADAM12 was not increased by TGF- $\beta$ treatment (Fig. $5 \mathrm{H}$ and I). RANKL treatment significantly increased the expression of Itgav, Itgb5 and ADAM12 (Fig. 5B, G and I). The changes in the expression level of Itgav and Itgb5 in response to treatment with RANKL with or without TGF- $\beta$ resembled those of MITF-E expression; RANKL increased the expression (Fig. 4B), but the extent of the increased gene expression was much smaller than that of the increase following co-treatment with TGF- $\beta$.

In the present study, DC-STAMP expression was increased by RANKL treatment, which coincides with the induction of MITF-E but not MITF-A. Previous studies showed that transcriptional activation of DC-STAMP, a master regulator of cell fusion during osteoclastogenesis, is regulated by $\mathrm{MITF}^{21,48}$ although isoform of MITF responsible for the cell fusion has not been identified. It is possible that one of the roles of MITF-E induces transcriptional activation of DC-STAMP. However, role of MITF-E expression in response to treatment with RANKL and TGF- $\beta$ is likely to be distinct from that with RANKL alone; the extent of further increase in DC-STAMP expression in response to TGF- $\beta$ was relatively smaller than that in MITF-E expression. Considering that TGF- $\beta$ formed larger osteoclasts with more nuclei, the further increased MITF-E by TGF- $\beta$ might regulate the transcription of gene(s) other than DC-STAMP, leading to acceleration of cell fusion. 
Integrins are involved in cell fusion as described above. ${ }^{11,13}$ In addition, integrin $\alpha 4$ (Itga4) expression is induced by MITF in hematopoietic stem/progenitor cells, ${ }^{49}$ and the regulatory expression of Itga4 depends on the isoform of MITF. ${ }^{33}$ Thus, we speculate that TGF- $\beta$-mediated up-regulation of MITF-E expression is responsible for the formation of larger osteoclasts through increased expression of integrins; especially, the regulatory expression of Itgav and Itgb5 may be important, because changes in expression of MITF-E paralleled to those of Itgav and Itgb5 in response to treatment with RANKL with or without TGF- $\beta$. The present results suggest the critical role of DC-STAMP and integrins in osteoclastogenesis induced by RANKL and in osteoclast maturation by TGF- $\beta$, respectively; MITF-E may regulate both processes.

The present study extends the knowledge of the expression and role of MITF-E expression in developing osteoclasts. We previously demonstrated the functional interaction between MITF and the TGF- $\beta$ pathway. TGF- $\beta$ enhances MITF-E-mediated transcription, ${ }^{30,} 31$ whereas the MITF-M isoform negatively regulates TGF- $\beta$-mediated signaling. ${ }^{50}$ In the present study, additional regulation of MITF activity by the TGF- $\beta$ pathway, i.e., enhancement of MITF expression by TGF- $\beta$, was clarified. Recently, it was shown that TGF- $\beta$ represses the transcription of MITF-M in melanoma cells. ${ }^{51}$ Taken the present results with the results of a previous study ${ }^{51}$ together, MITF expression may be regulated by TGF- $\beta$ in an isoform- or cell type-dependent manner or both.

Balancing bone resorption and bone formation is important for bone and mineral homeostasis. Differentiation into multinucleated TRAP-positive cells resulting from the fusion of monocyte/macrophage lineage cells is a critical step in determining osteoclast activity. Therefore, fine-tuning of osteoclastogenesis through the regulation of TGF- $\beta$ activity is likely to maintain preferable bone mass. Further studies are needed to clarify 
the molecular mechanisms underlying the regulation of MITF-E expression by TGF- $\beta$, osteoclast formation and maturation by MITF-E and the regulatory expression of integrins by MITF-E and TGF- $\beta$.

\section{CONFLICT OF INTEREST}

The authors declare no conflict of interest.

\section{ACKNOWLEDGEMENTS}

This work was supported by a Grant-in-Aid for Scientific Research (24580437) from The Japan Society for the Promotion of Science and a research project grant awarded by Azabu University. 


\section{References}

1. Blair HC. How the osteoclast degrades bone. Bioessays 1998; 20:837-846.

2. Bar-Shavit Z. The osteoclast: a multinucleated, hematopoietic-origin, bone-resorbing osteoimmune cell. J Cell Biochem 2007; 102:1130-1139.

3. Nakamura I, Takahashi N, Jimi E, Udagawa N, Suda T. Regulation of osteoclast function. Mod Rheumatol 2012; 22:167-177.

4. Boyle WJ, Simonet WS, Lacey DL. Osteoclast differentiation and activation. Nature 2003; 423:337-342.

5. Negishi-Koga T, Takayanagi $\mathrm{H}$. $\mathrm{Ca}^{2+}$-NFATc1 signaling is an essential axis of osteoclast differentiation. Immunol Rev 2009; 231:241-256.

6. Fox SW, Lovibond AC. Current insights into the role of transforming growth factor- $\beta$ in bone resorption. Mol Cell Endocrinol 2005; 243:19-26.

7. Janssens K, ten Dijke P, Janssens S, Van Hul W. Transforming growth factor- $\beta 1$ to the bone. Endocr Rev 2005; 26:743-774.

8. Alliston T, Piek E, Derynck R. 2008. TGF- $\beta$ family signaling in skeletal development, maintenance, and disease. In The TGF- $\beta$ Family, Derynck $\mathrm{R}$, Miyazono K (eds.); Cold Spring Harbor Laboratory Press: Cold Spring Harbor; 667-723.

9. Koseki T, Gao Y, Okahashi N, Murase Y, Tsujisawa T, Sato T, Yamato K, Nishihara T. Role of TGF- $\beta$ family in osteoclastogenesis induced by RANKL. Cell Signal 2002; 14:31-36.

10. Shui C, Riggs BL, Khosla S. The immunosuppressant rapamycin, alone or with transforming growth factor- $\beta$, enhances osteoclast differentiation of RAW264.7 monocyte-macrophage cells in the presence of RANK-ligand. Calcif Tissue Int 2002; 71:437-446.

11. Chin SL, Johnson SA, Quinn J, Mirosavljevic D, Price JT, Dudley AC, Thomas DM. A role for $\alpha \mathrm{V}$ integrin subunit in TGF- $\beta$-stimulated osteoclastogenesis. Biochem Biophys Res Commun 2003; 307:1051-1058.

12. Hodgkinson CA, Moore KJ, Nakayama A, Steingrímsson E, Copeland NG, Jenkins NA, Arnheiter H. Mutations at the mouse microphthalmia locus are associated with defects in a gene encoding a novel basic-helix-loop-helix-zipper protein. Cell 1993; 74:395-404.

13. Ooishi R, Shirai M, Funaba M, Murakami M. Microphthalmia-associated transcription factor is required for mature myotube formation. Biochim Biophys Acta 2012; 1820:76-83.

14. Weilbaecher KN, Motyckova G, Huber WE, Takemoto CM, Hemesath TJ, Xu Y, 
Hershey CL, Dowland NR, Wells AG, Fisher DE. Linkage of M-CSF signaling to Mitf, TFE3, and the osteoclast defect in Mitf(mi/mi) mice. Mol Cell 2001; 8:749-758.

15. Hershey CL, Fisher DE. Mitf and Tfe3: members of a b-HLH-ZIP transcription factor family essential for osteoclast development and function. Bone 2004; 34:689-696.

16. Luchin A, Purdom G, Murphy K, Clark MY, Angel N, Cassady AI, Hume DA, Ostrowski MC. The microphthalmia transcription factor regulates expression of the tartrate-resistant acid phosphatase gene during terminal differentiation of osteoclasts. J Bone Miner Res 2000; 15:451-460.

17. Meadows NA, Sharma SM, Faulkner GJ, Ostrowski MC, Hume DA, Cassady AI. The expression of Clcn7 and Ostm1 in osteoclasts is coregulated by microphthalmia transcription factor. J Biol Chem 2007; 282:1891-1904.

18. Motyckova G, Weilbaecher KN, Horstmann M, Rieman DJ, Fisher DZ, Fisher DE. Linking osteopetrosis and pycnodysostosis: regulation of cathepsin $\mathrm{K}$ expression by the microphthalmia transcription factor family. Proc Natl Acad Sci U S A 2001; 98:5798-5803.

19. Feng H, Cheng T, Steer JH, Joyce DA, Pavlos NJ, Leong C, Kular J, Liu J, Feng X, Zheng $\mathrm{MH}$, Xu J. Myocyte enhancer factor 2 and microphthalmia-associated transcription factor cooperate with NFATc1 to transactivate the V-ATPase d2 promoter during RANKL-induced osteoclastogenesis. J Biol Chem 2009; 284:14667-14676.

20. Yagi M, Miyamoto T, Sawatani Y, Iwamoto K, Hosogane N, Fujita N, Morita K, Ninomiya K, Suzuki T, Miyamoto K, Oike Y, Takeya M, Toyama Y, Suda T. DC-STAMP is essential for cell-cell fusion in osteoclasts and foreign body giant cells. J Exp Med 2005; 202:345-351.

21. Courtial N, Smink JJ, Kuvardina ON, Leutz A, Göthert JR, Lausen J. Tal1 regulates osteoclast differentiation through suppression of the master regulator of cell fusion DC-STAMP. FASEB J 2012; 26:523-532.

22. Steingrímsson E, Copeland NG, Jenkins NA. Melanocytes and the microphthalmia transcription factor network. Annu Rev Genet 2004; 38:365-411.

23. Hou L, Pavan WJ. Transcriptional and signaling regulation in neural crest stem cell-derived melanocyte development: do all roads lead to Mitf? Cell Res 2008; 18:1163-1176.

24. Vachtenheim J, Borovanský J. "Transcription physiology" of pigment formation in melanocytes: central role of MITF. Exp Dermatol 2010; 19:617-627. 
25. Amae S, Fuse N, Yasumoto K, Sato S, Yajima I, Yamamoto H, Udono T, Durlu YK, Tamai M, Takahashi K, Shibahara S. Identification of a novel isoform of microphthalmia-associated transcription factor that is enriched in retinal pigment epithelium., Biochem Biophys Res Commun 1998; 247:710-715.

26. Takemoto CM, Yoon YJ, Fisher DE. The identification and functional characterization of a novel mast cell isoform of the microphthalmia-associated transcription factor. J Biol Chem 2002; 277:30244-30252.

27. Murakami M, Iwata Y, Funaba M. Expression and transcriptional activity of alternative splice variants of Mitf exon 6. Mol Cell Biochem 2007; 303:251-257.

28. Bharti K, Liu W, Csermely T, Bertuzzi S, Arnheiter H. Alternative promoter use in eye development: the complex role and regulation of the transcription factor MITF. Development 2008; 135:1169-1178.

29. Murakami M, Ikeda T, Ogawa K, Funaba M. Transcriptional activation of mouse mast cell protease- 9 by microphthalmia-associated transcription factor. Biochem Biophys Res Commun 2003; 311:4-10.

30. Funaba M, Ikeda T, Murakami M, Ogawa K, Abe M. Up-regulation of mouse mast cell protease-6 gene by transforming growth factor- $\beta$ and activin in mast cell progenitors. Cell Signal 2005; 17:121-128.

31. Murakami M, Ikeda T, Saito T, Ogawa K, Nishino Y, Nakaya K, Funaba M. Transcriptional regulation of plasminogen activator inhibitor-1 by transforming growth factor- $\beta$, activin A and microphthalmia-associated transcription factor. Cell Signal 2006; 18:256-265.

32. Park HY, Wu C, Yonemoto L, Murphy-Smith M, Wu H, Stachur CM, Gilchrest BA. MITF mediates cAMP-induced protein kinase C-beta expression in human melanocytes. Biochem J 2006; 395:571-578.

33. Shahlaee AH, Brandal S, Lee YN, Jie C, Takemoto CM. Distinct and shared transcriptomes are regulated by micophtalmia-associated transcription factor isoforms in mast cells. J Immunol 2007; 178:378-388.

34. Sankar U, Patel K, Rosol TJ, Ostrowski MC. RANKL coordinates cell cycle withdrawal and differentiation in osteoclasts through the cyclin-dependent kinase inhibitors p27KIP1 and p21CIP1. J Bone Miner Res 2004; 19:1339-1348.

35. Murakami M, Kawachi H, Ogawa K, Nishino Y, Funaba M. Receptor expression modulates the specificity of transforming growth factor- $\beta$ signaling pathways. Genes Cells 2009; 14:469-482.

36. Islam S, Hassan F, Tumurkhuu G, Dagvadorj J, Koide N, Naiki Y, Yoshida T, Yokochi T. Receptor activator of nuclear factor- $\kappa \mathrm{B}$ ligand induces osteoclast 
formation in RAW 264.7 macrophage cells via augmented production of macrophage-colony-stimulating factor. Microbiol Immunol 2008; 52:585-590.

37. Lu SY, Li M, Lin YL. Mitf induction by RANKL is critical for osteoclastogenesis. Mol Biol Cell 2010; 21:1763-1771.

38. Ishida N, Hayashi K, Hoshijima M, Ogawa T, Koga S, Miyatake Y, Kumegawa M, Kimura T, Takeya T. Large scale gene expression analysis of osteoclastogenesis in vitro and elucidation of NFAT2 as a key regulator. J Biol Chem 2002; 277:41147-41156.

39. Takayanagi H, Kim S, Koga T, Nishina H, Isshiki M, Yoshida H, Saiura A, Isobe M, Yokochi T, Inoue J, Wagner EF, Mak TW, Kodama T, Taniguchi T. Induction and activation of the transcription factor NFATc1 (NFAT2) integrate RANKL signaling in terminal differentiation of osteoclasts. Dev Cell 2002; 3:889-901.

40. Yagi M, Miyamoto T, Toyama Y, Suda T. Role of DC-STAMP in cellular fusion of osteoclasts and macrophage giant cells. J Bone Miner Metab 2006; 24:355-358.

41. Oursler MJ. Recent advances in understanding the mechanisms of osteoclast precursor fusion. J Cell Biochem 2010; 110:1058-1062.

42. Brodbeck WG, Anderson JM. Giant cell formation and function. Curr Opin Hematol 2009; 16:53-57.

43. Hughes DE, Salter DM, Dedhar S, Simpson R. Integrin expression in human bone. J Bone Miner Res 1993; 8:527-533.

44. Rao H, Lu G, Kajiya H, Garcia-Palacios V, Kurihara N, Anderson J, Patrene K, Sheppard D, Blair HC, Windle JJ, Choi SJ, Roodman GD. $\alpha 9 \beta 1$ : a novel osteoclast integrin that regulates osteoclast formation and function. $J$ Bone Miner Res 2006; 21:1657-1665.

45. Faccio R, Takeshita S, Zallone A, Ross FP, Teitelbaum SL. c-Fms and the $\alpha \mathrm{v} \beta 3$ integrin collaborate during osteoclast differentiation. J Clin Invest 2003; 111:749-758.

46. Abe E, Mocharla H, Yamate T, Taguchi Y, Manolagas SC. Meltrin- $\alpha$, a fusion protein involved in multinucleated giant cell and osteoclast formation. Calcif Tissue Int 1999; 64:508-515.

47. Choi SJ, Han JH, Roodman GD. ADAM8: a novel osteoclast stimulating factor. $J$ Bone Miner Res 2001; 16:814-822.

48. Maruyama K, Uematsu S, Kondo T, Takeuchi O, Martino MM, Kawasaki T, Akira S. Strawberry notch homologue 2 regulates osteoclast fusion by enhancing the expression of DC-STAMP. J Exp Med 2013; 210:1947-1960.

49. Khurana S, Buckley S, Schouteden S, Ekker S, Petryk A, Delforge M, Zwijsen A, 
Verfaillie CM. A novel role of BMP4 in adult hematopoietic stem and progenitor cell homing via Smad independent regulation of integrin- $\alpha 4$ expression. Blood 2013; 121:781-790.

50. Funaba M, Ikeda T, Murakami M, Ogawa K, Tsuchida K, Sugino H, Abe M. Transcriptional activation of mouse mast cell protease-7 by activin and transforming growth factor- $\beta$ is inhibited by microphthalmia-associated transcription factor. J Biol Chem 2003; 278:52032-52041.

51. Pierrat MJ, Marsaud V, Mauviel A, Javelaud D. Expression of microphthalmia-associated transcription factor (MITF), which is critical for melanoma progression, is inhibited by both transcription factor GLI2 and transforming growth factor- $\beta$. J Biol Chem 2012; 287:17996-18004. 


\section{Figure legends}

\section{Figure 1. MITF-E is induced during osteoclastogenesis}

Gene transcript levels of the MITF-A isoform (A and B) and MITF-E isoform (C and D) were quantified by RT-qPCR during osteoclastogenesis in RAW264.7 macrophage cells (A and C) and primary cultures of bone marrow cells (B and D). (A and C) RAW264.7 cells were treated with or without RANKL (100 ng/ml) for 3 days. (B and D) Bone marrow cells were treated with M-CSF (50 ng/ml) for 3 days. Non-adherent cells were subsequently treated with M-CSF (50 ng/ml) with or without RANKL (100 ng/ml) for an additional 3 days. The expression of the MITF isoforms was normalized to G3PDH expression $(\mathrm{n}=3)$. ${ }^{* *}: \mathrm{P}<0.01$.

Figure 2. MITF-E expression is required for osteoclastogenesis

RAW264.7 cells were transfected with MITF-E siRNA or GFP, or treated with RNA transfection reagent only (mock). At 8 hours after transfection, the cells were treated with or without RANKL (100 ng/ml) for 3 days. (A) The cells were stained for TRAP and counter-stained with hematoxylin. A representative result is shown. *: TRAP-positive multinucleated cell. The bar in each photograph indicates $100 \mu \mathrm{m}$. (B) The number of TRAP-positive multinucleated cells in a well of 96-well plate was counted ( $\mathrm{n}=3)$. (C-F) The gene transcript level of MITF-E (C) and MITF-A (D) on day 1, and that of TRAP (E) and CtsK (F) on day 3 were quantified by RT-qPCR, and the expression was normalized to G3PDH expression. The expression in cells treated with siRNA for GFP was set to $1(\mathrm{n}=3){ }^{*}$ and $* *$ : $P<0.05$ and $P<0.01$, respectively.

\section{Figure 3. TGF- $\beta$ enhances RANKL-induced osteoclastogenesis}

RAW264.7 cells were pre-treated with or without TGF- $\beta 1$ (100 pM) for 12 hours, followed by the co-treatment with or without RANKL (100 ng/ml) for 3 days. (A) Cells were stained for TRAP and counter-stained with hematoxylin. A representative result is 
shown. *: TRAP-positive multinucleated cell. The bar in each photograph indicates 100 $\mu \mathrm{m}$. (B) The total number of TRAP-positive multinucleated cells in a well of 96-well plate was counted $(n=3)$. (C) The number of TRAP-positive multinucleated cells induced by RANKL alone or RANKL plus TGF- $\beta$ was counted for every cell size. The percentage of the respective TRAP-positive multinucleated cell number to the total TRAP-positive multinucleated cell number was calculated $(n=3)$. (D) Osteoclast functionality was evaluated by pit formation assays $(n=3)$. A representative result is shown. The bar in each photograph indicates $100 \mu \mathrm{m}$. (E) The total area of pit in a well of 96-well plate was measured $(\mathrm{n}=3)$. **: $P<0.01$.

Figure 4. TGF- $\beta$ enhances expression of MITF-E and genes related to osteoclastogenesis

RAW264.7 cells were pre-treated with or without TGF- $\beta 1$ (100 pM) for 12 hours, followed by the co-treatment with RANKL (100 ng/ml) for 3 days. The gene transcript levels of NFATc1 (A), MITF-E (B) and MITF-A (C) on day 1 and TRAP (D) and CtsK (E) on day 3 were quantified by RT-qPCR. The expression was normalized to G3PDH expression, and the expression in cells treated without RANKL and TGF- $\beta 1$ was set to $1(\mathrm{n}=3) . * *: P<0.01$.

Figure 5. TGF- $\beta$ increases expression of genes related to cell adhesion and fusion

RAW264.7 cells were pre-treated with or without TGF- $\beta 1$ (100 pM) for 12 hours, followed by the co-treatment with RANKL (100 ng/ml) for 3 days. The gene transcript levels of DC-STAMP (A), ItgaV (B), Itga2 (C), Itga5 (D), Itgb1 (E), Itgb3 (F), Itgb5 (G), ADAM8 (H) and ADAM12 (I) on day 3 were quantified by RT-qPCR. The expression was normalized to G3PDH expression, and the expression in cells treated without RANKL and TGF- $\beta 1$ was set to $1(\mathrm{n}=3)$. ${ }^{*}$ and $* *: P<0.05$ and $P<0.01$, 
respectively. 
Table 1. Oligonucleotide PCR primers for RT- $\mathrm{qPCR}$

Oligonucleotide

\begin{tabular}{ll} 
& \multicolumn{1}{c}{ 5'-primer } \\
\hline MITF: & 5'-GAGGAGTTTCACGAAGAACC-3' \\
MITF-A & 5'-CCAGATACACAGACAGTCACAG-3' \\
MITF-E & \\
& \\
Osteoclast-related genes' \\
NFATc1 & 5'-TCCAAAGTCATTTTCGTGGA-3' \\
TRAP & 5'-GCCAAAGAGATCGCCAGAAC-3' \\
CtsK & 5'-TGGACTGTGTGACTGAGAATTATG \\
& \\
Cell fusion-related genes'- \\
DC-STAMP & 5'-CGAAGCTCCTTGAGAAACGA-3' \\
Itgav & 5'-GGTGTGGATCGAGCTGTCTT-3' \\
Itga2 & 5'-ACTTCCGGCATACGAAAGAAT-3' \\
Itga5 & 5'-CACCATTCAATTTGACAGCAA-3' \\
Itgb1 & 5'-ATGCAGGTTGCGGTTTGT-3' \\
Itgb3 & 5'-GTGGGAGGGCAGTCCTCTA-3' \\
Itgb5 & 5'-TGCCACCTGCCAAGATGGCATA-3' \\
ADAM8 & 5'-AAAGGCTCCGAGACAAATCC-3' \\
ADAM12 & 5'-CAGAGCATCCCAGCCAAG-3'
\end{tabular}

MITF-A

steoclast-related genes:
NFATc
5'-GCCAAAGAGATCGCCAGAAC- 3
5-TGGACTGTGTGACTGAGAATTATGG-3'

GenBank

accession number

AB_009397

5'-GCTGGCGTAGCAAGATGCGTGA-3'

5'-GCTGGCGTAGCAAGATGCGTGA-3'

AF 465624

5'CTTTGCTTCCATCTCCCAGA-3'

5'-GAAGTAGAAATTGTCCCCCAGAGA-3'

NM_016791

NM_007388

5'CCGTTCTGCTGCACGTATTG-3'

NM_007802

AB_109560

5'-GGACTGGAAACCAGAAATGAA-3'

5'CAAGGCCAGCATTTACAGTG-3'

NM 008402

5'-TCAGCCAGCAGGTGATGTTA-3'

5'-TCCTCTCCCTTGGCACTGTA-3'

5'CATCCGTGGAAAACACCAG-3'

5'CAGGATATCAGGACCCTTGG-3'

5'-CACGGACACTTCAAAGGATG-3'

5'TTGGAGAGCCCCGAGATAG-3'

5'CAGGCTGAGGATCAGGTCTC-3'

NM_008396

NM_010577

NM_010578

NM 016780

NM_010580

NM_007403

NM_007400

Housekeeping gene: 
A

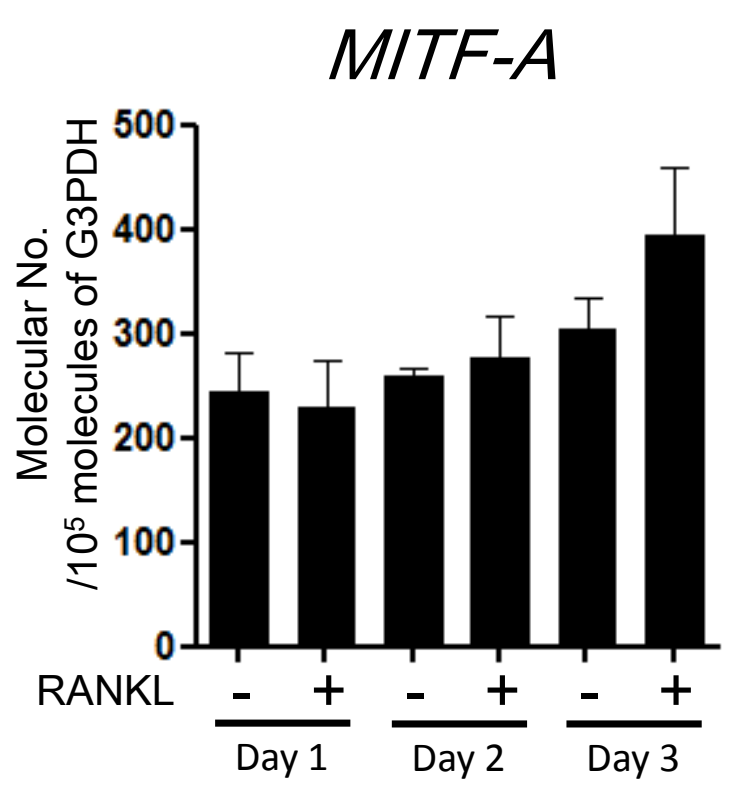

C

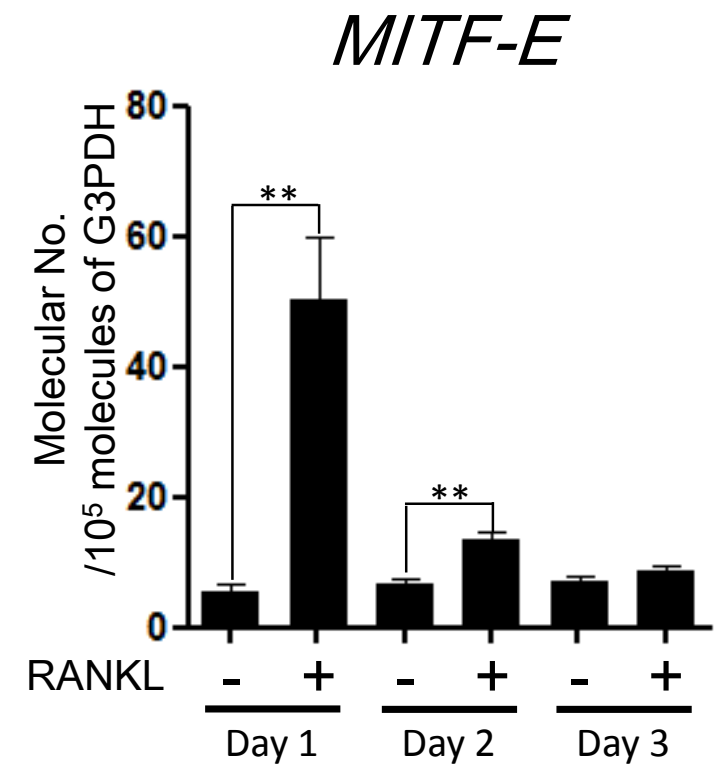

B

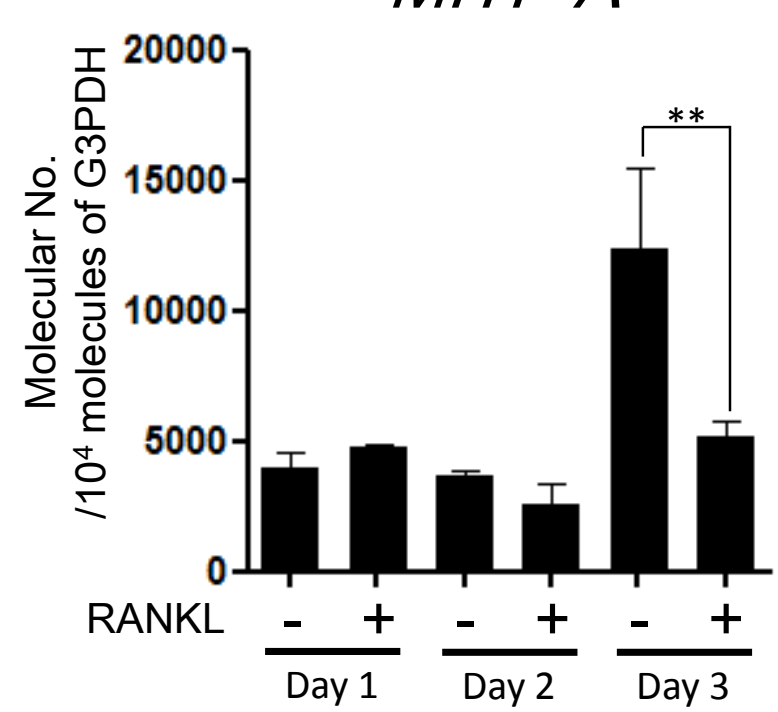

D

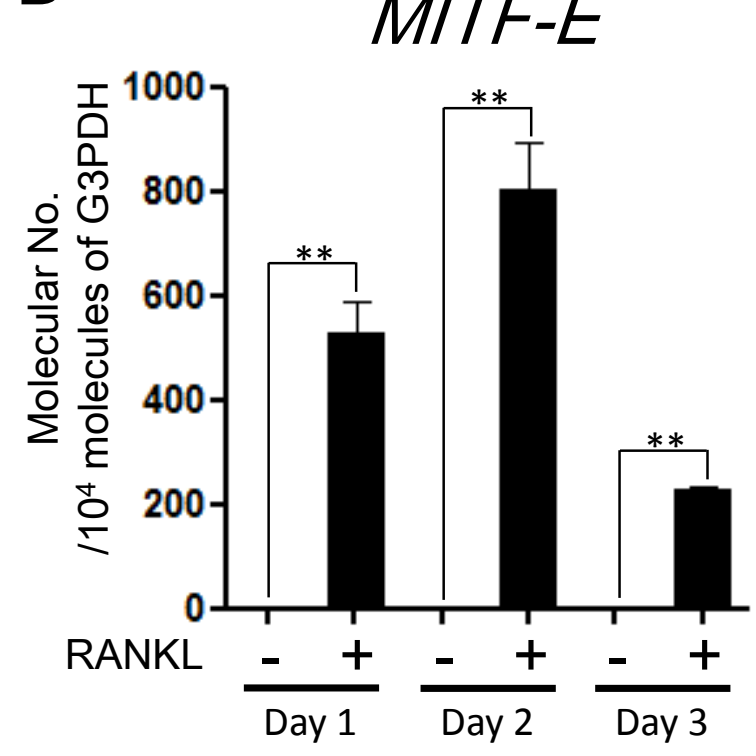


A

B

RNAi:
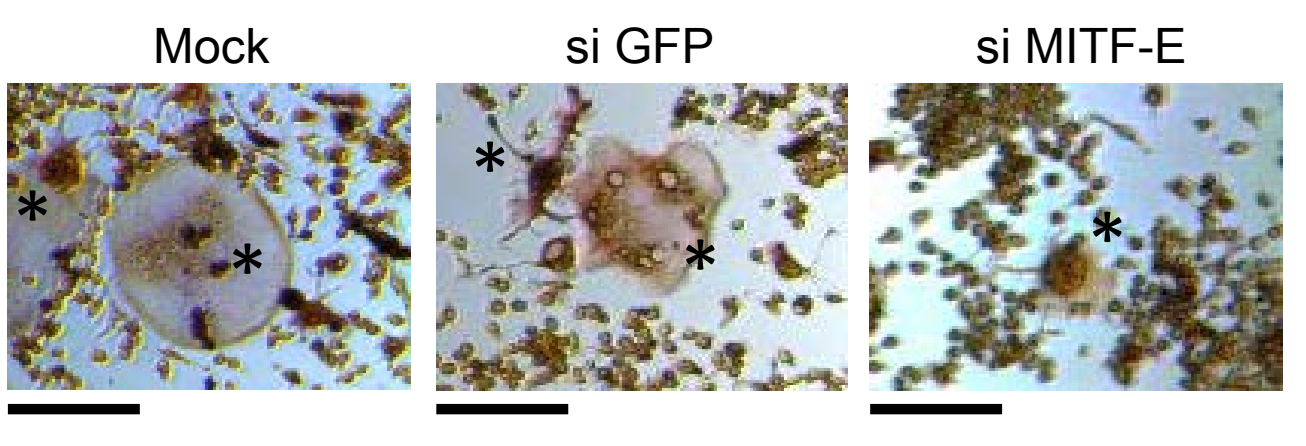

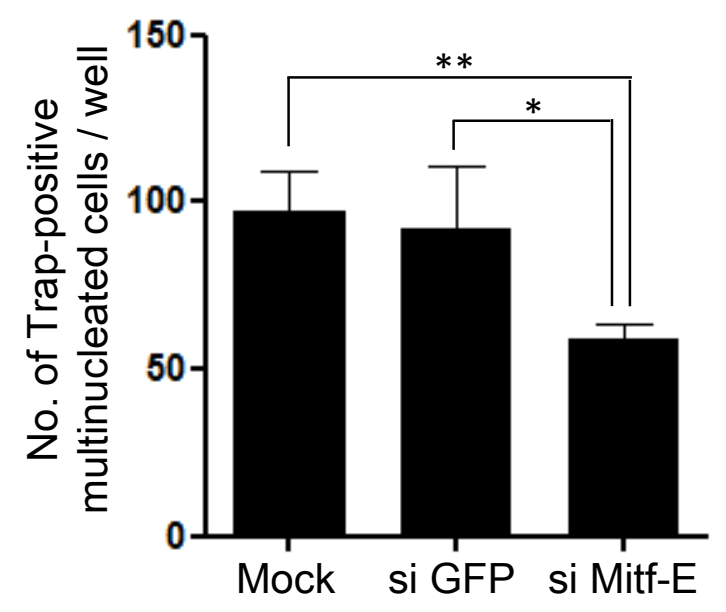

E MITF-A

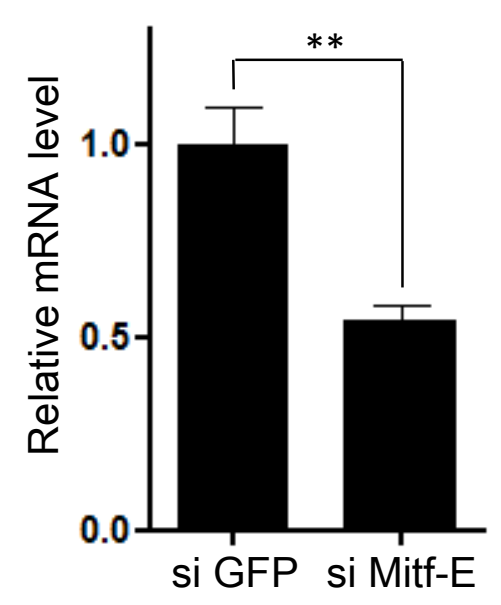

c MITF-E

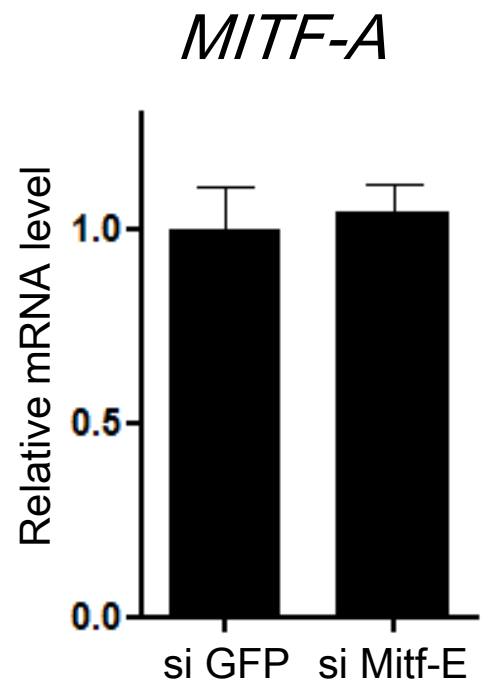

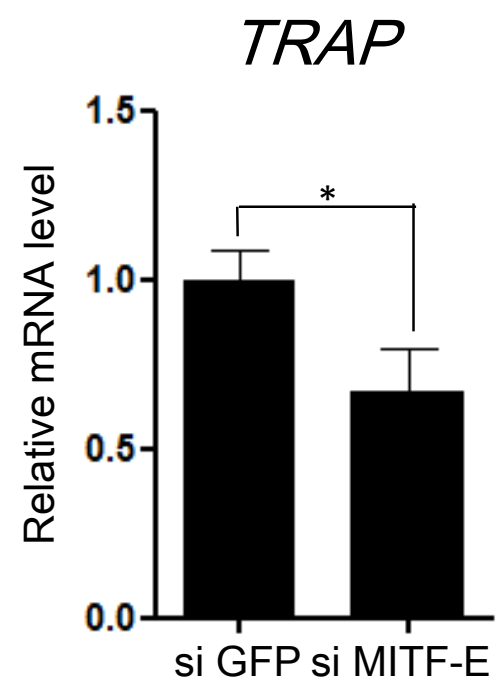

F

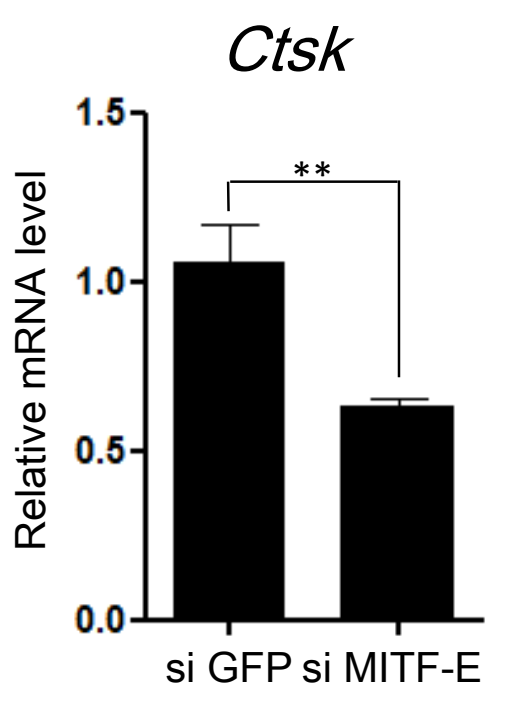


RANKL: TGF- $\beta$ :

C

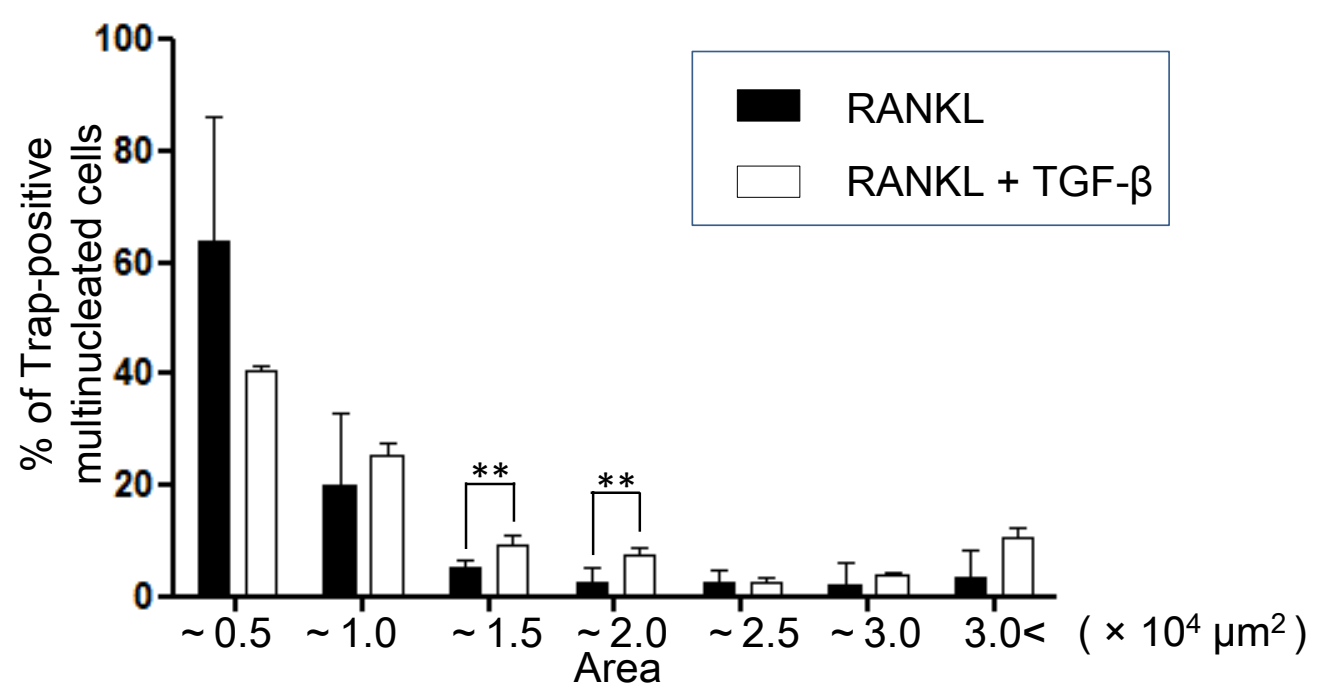

D

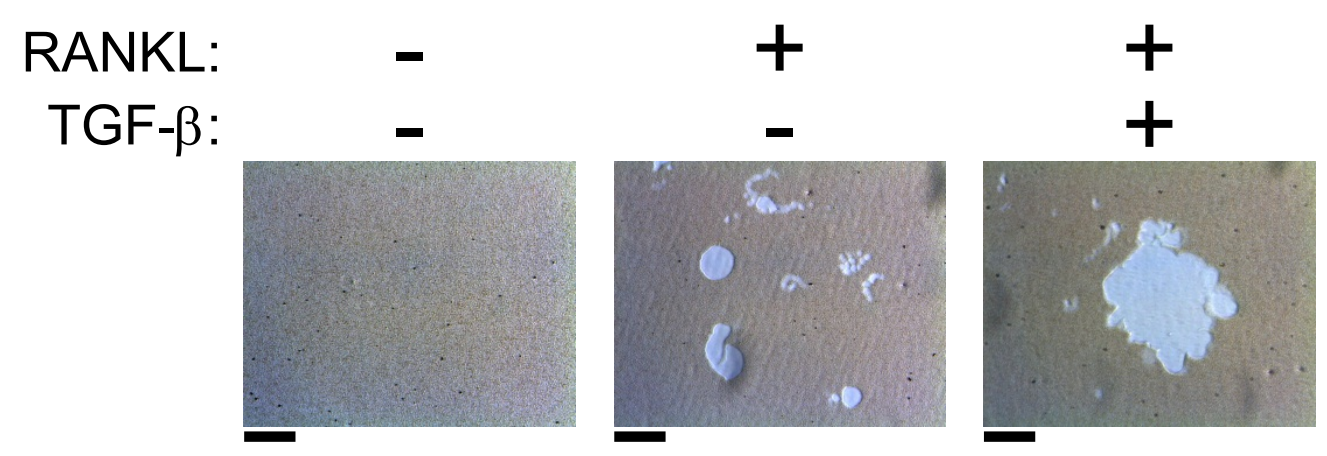

B

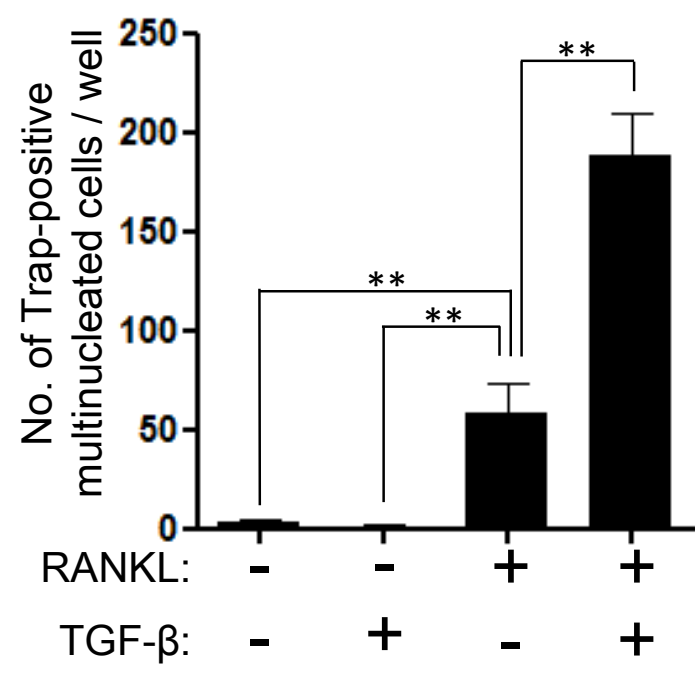

E

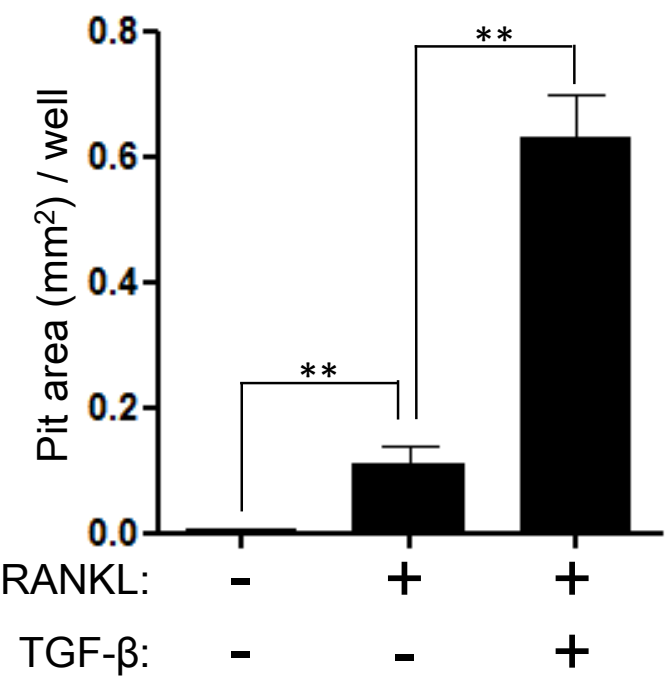


A

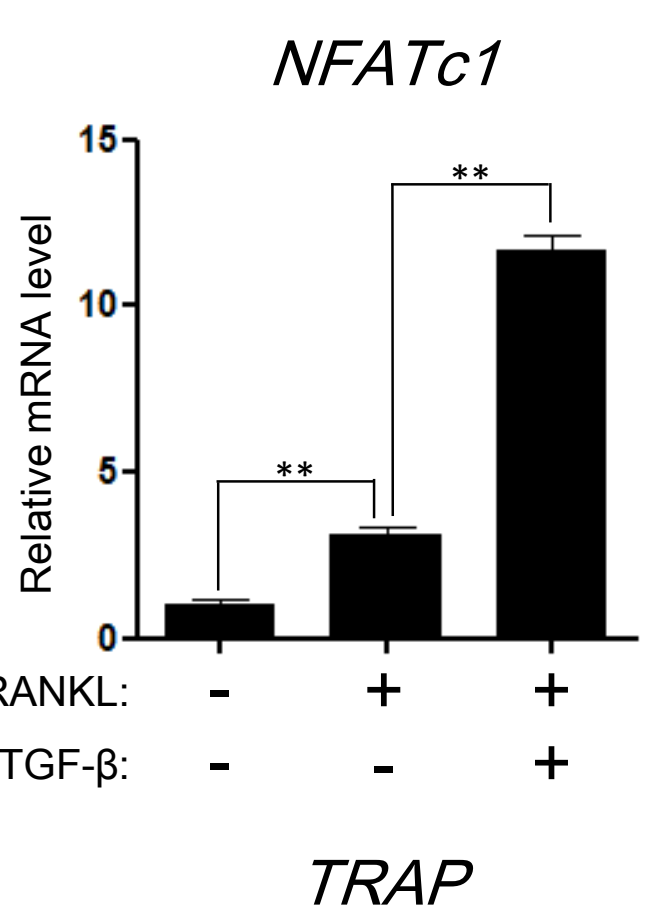

D

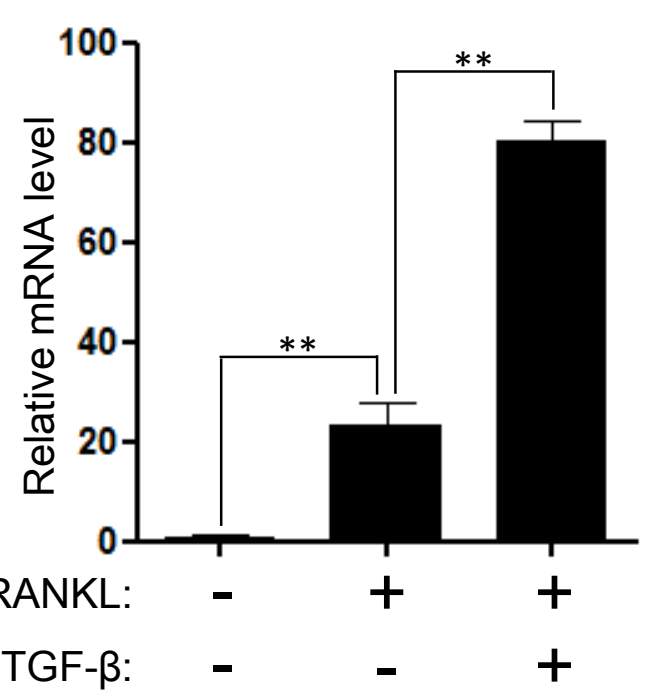

B

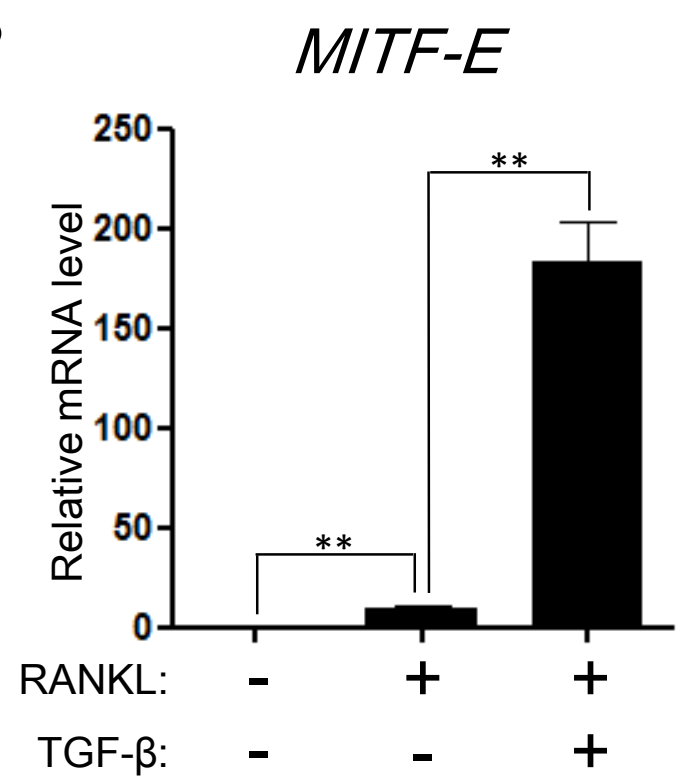

E

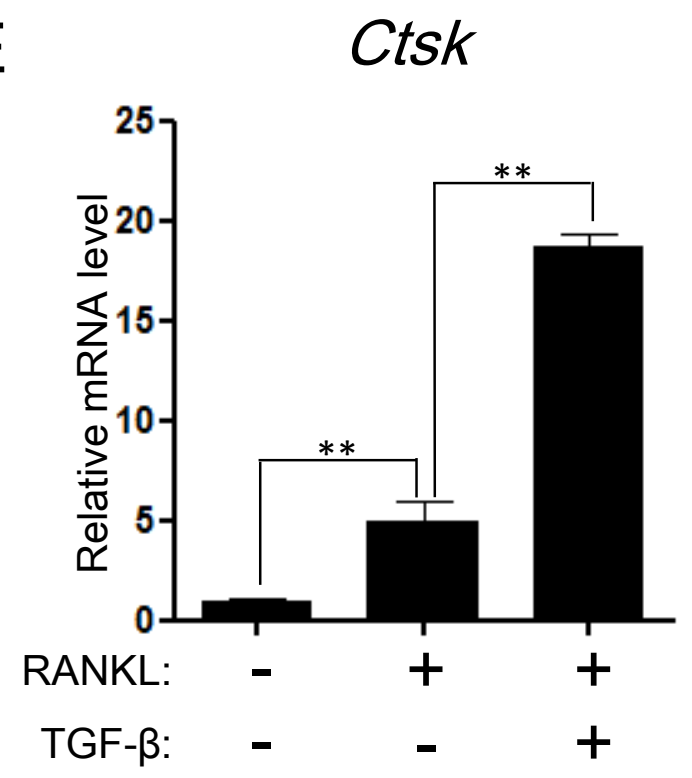

E
C

MITF-A

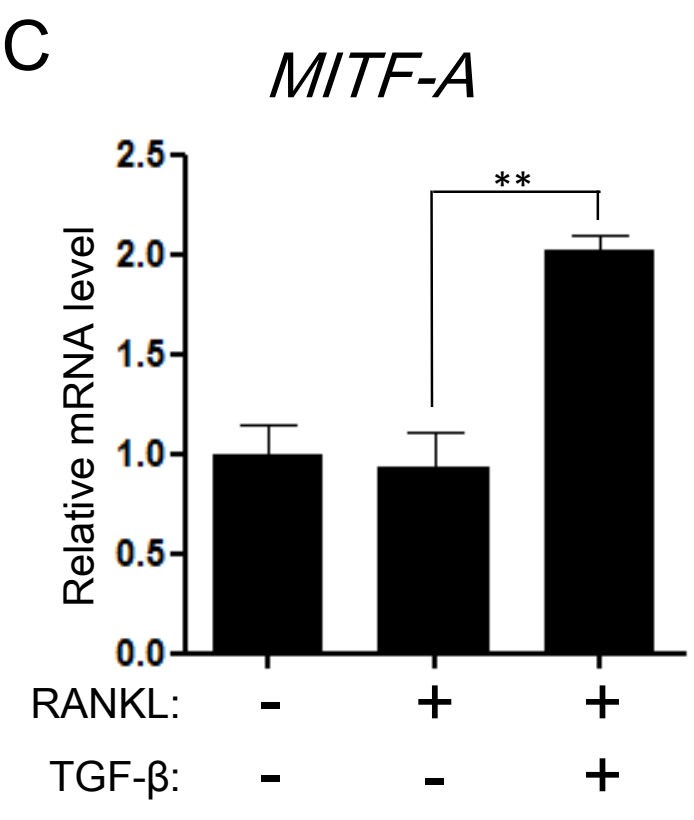




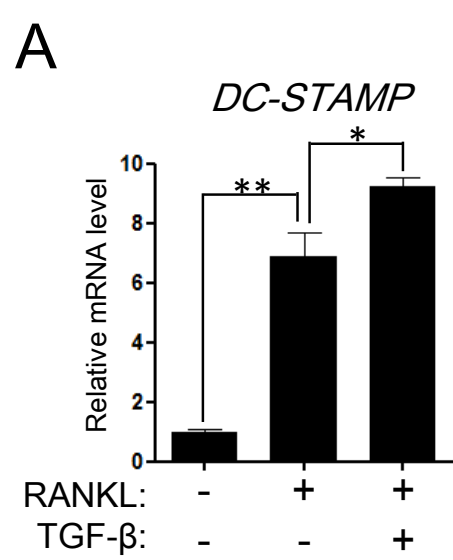

B

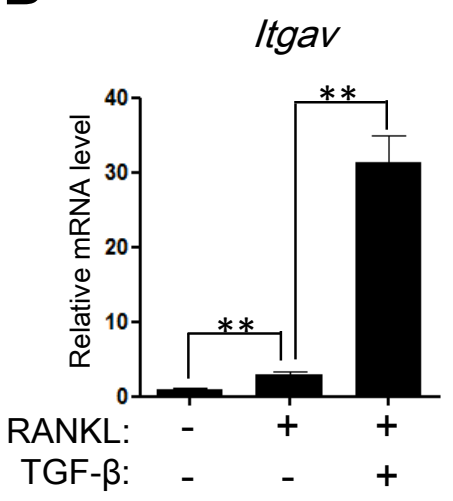

E

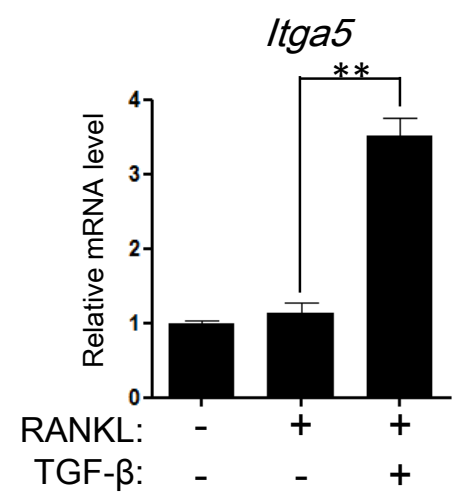

G

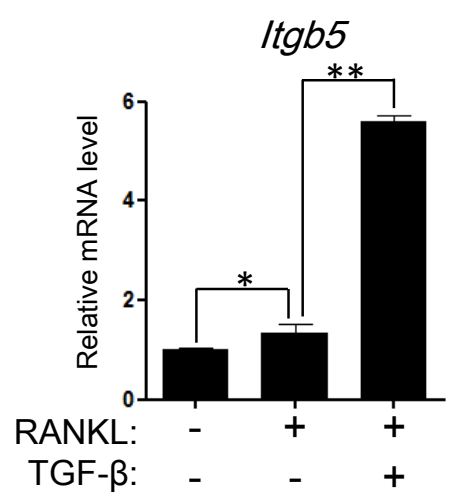

$\mathrm{H}$

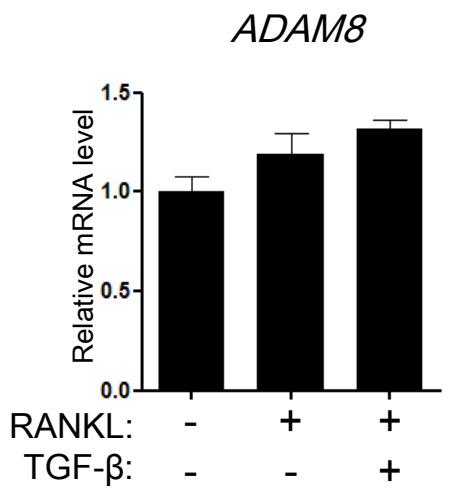

C

Itga2

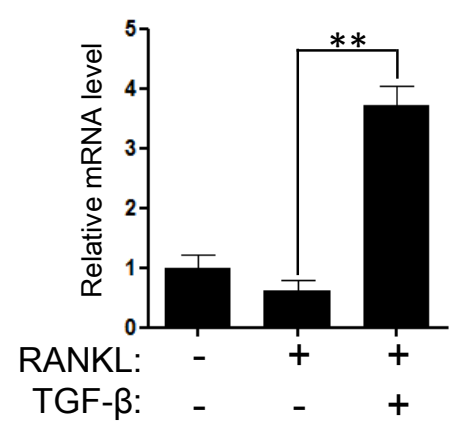

F

$\operatorname{ltg} b 3$

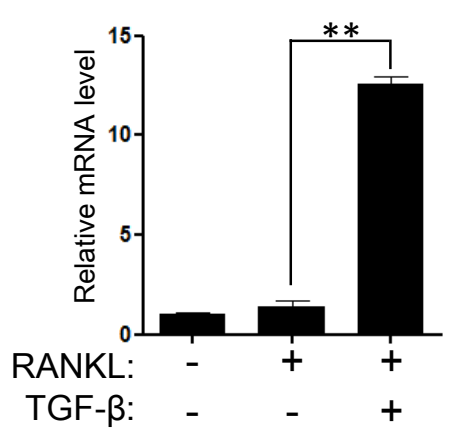

I

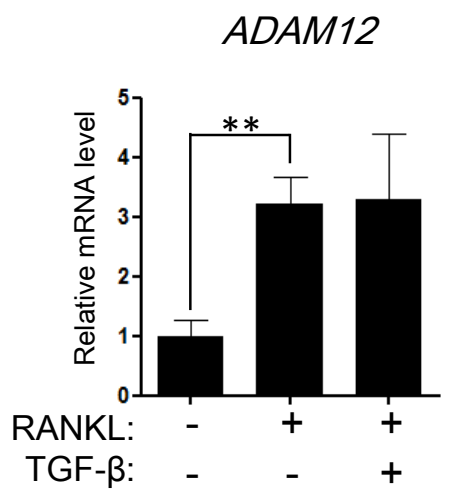

